\title{
Right Unilateral Myelin Fiber
}

\section{Diallo Seydou ${ }^{1 *}$, Conaré Ibrahima ${ }^{2}$, Sidibé Mohamed Kolé ${ }^{1}$, Coulibaly Brainima ${ }^{1}$, Diallo Hamadoun ${ }^{1}$ and Elien Gagnan Yan-zaou-tou Rodrigue Romuald ${ }^{1}$}

\author{
${ }^{1}$ Institute of Tropicale of Ophthalmology of Africa (Bamako), France, Europe \\ ${ }^{2}$ Gao Regional Hospital (Mali), France, Europe \\ *Corresponding Author: Diallo Seydou, Institute of Tropicale of Ophthalmology \\ of Africa (Bamako), France, Europe.
}

DOI: 10.31080/ASOP.2020.03.0092
Received: January 19, 2020

Published: February 10, 2020

(C) All rights are reserved by Diallo Seydou., et al.

Abstract

Introduction: Myelin fibers correspond to the abnormal presence of myelin around the retinal optic fibers.

Clinical Observation: It was a 22-year-old patient who presented with an examination of the fundus at the level of the right eye an extensive whitish cupboard, papillary, peri-papillary, scalloped plan hiding the retinal vessels.

Discussion: Myelin fibers are congenital abnormalities of the papilla. The papillary, peri-papillary and distance localization of the papilla found in our study has been noted in the literature. Myopia occurs during extensive myelin fibers as in our patient.

Conclusion: Myelin fibers are rare, asymptomatic, benign affections, discovered incidentally during an eye examination, the diagnosis is essentially clinical.

Keywords: Myelin Fiber; Anomalies; Myelination Mali

\section{Introduction}

Myelin fibers correspond to the abnormal presence of myelin around the retinal optic fibers. The pathogenesis of myelin fibers remains unknown. Indeed, the myelination of the optic nerve begins during fetal life progressing from optical radiation towards the eyeball to the posterior part of the screened lamina. This phenomenon stops shortly before birth. For $1 \%$ of the population, myelination will continue, after birth, beyond the screened blade to extend to the level of the anterior portion of the optic nerve and to the level of the sensory retina. Histologically, myelin fibers correspond to layers of myelin, accompanied by glial cells of oligodendrocytes type, surrounding the retinal fibers. The underlying retina is strictly normal [1]. Myelin fibers can however give rise to misdiagnosis with the other papilla elevation anomalies that are:

- Bergmeister's papilla: this is an infrequent unilateral abnormality that stems from incomplete regression of the avascular remains of the hyaloid system. It results in an uplift of glial tissue on the surface of the papilla.
- Papillary druses: which appear in the form of semi-translucent more or less coalescing blisters of the papilla without physiological excavation. Giving a yellowish pink coloring to the papillae whose edges are blurred and irregular. They correspond to the accumulation of hyaline deposits on the papilla.

- Cottony nodules: comparable to ill-defined cotton balls placed on the retina. They are reflected on the optical coherence tomography by a thickening of the retinal tissue which is focal, more important and well visualized with an underlying hypo reflectivity.

- $\quad$ Outbreaks of papillary juxta chorioretinitis

- $\quad$ Retinoblastoma, in case of localized myelin fibers [2]. We report a case with right unilateral myelin fibers.

\section{Clinical observation}

It was a 22-year-old patient who presented visual acuity on both eyes with the ophthalmological examination without correction quantified at 8/10 and with correction quantified at 10/10 (- 0.75 
diopters with the right eye and - 0.5 diopter with the left eye), the examination of the anterior segment was without particularity and the ocular tone was encrypted $12 \mathrm{mmhg}$ at the level of the two eyes. The examination of the fundus found at the level of the right eye an extensive whitish cupboard, papillary, peri-papillary, scalloped plan with edge masking the retinal vessels (Figure 1: A, C F, G). We did not notice any visual field defects. There was no delay in filling or signs of leakage during fluorescein angiography sequences of the right eye (Figure 1: I, J). Optical coherence tomography showed hyper-reflectivity and enlargement of the layer of nerve fibers and ganglion cells and irregularity of the outer layers (Figure 1: L). The examination of the left eye was normal (Figure 1: D, E, H, K and M). The patient was informed and reassured about the mild nature of the disease, and the need for clinical monitoring due to the risk of neovascularization.
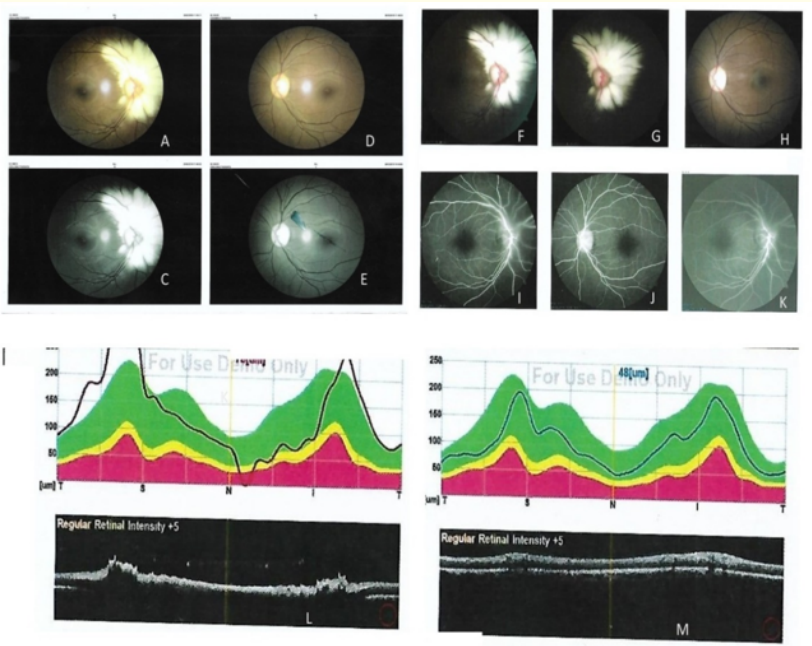

Figure 1: A, F, G: color photograph of the right eye showing an extensive whitish, papillary, peripapillary cup corresponding to the myelin fiber.

C: green image of the right eye showing the papillary and peripapillary myelin fiber.

I, K: Medium and late time image of fluorescein angiographic sequence without delay in filling or signs of leaks.

L: Horizontal sections of optical coherence tomography of right eye objectifying hyper reflectivity and hypertrophy of the layer of nerve fibers and ganglion cells and irregularity of the outer layers. $\mathrm{H}$ : color photograph of the left eye normal.

M: Horizontal sections of optical coherence tomography of left eye normal.

\section{Discussion}

Myelin fibers are congenital abnormalities of the papilla [3], they are rare conditions. Straatsma [4] noted an incidence of $0.98 \%$ on 4000 autopsies. Some authors found an incidence of $0.57 \%$ on 5789 patients. Myelin fibers can be associated with impairment of the visual field, most often a widening of the blind spot [5]. In our study, there was no visual field impairment. The papillary, peripapillary and distance localization of the papilla found in our study has been noted in the literature [6]. Myopia occurs during extensive myelin fibers [7] as in our patient. The hypofluorescence of the fundus at fluorescein angiography found in our study has been noted in the literature [8,9]. The hyper-reflectivity of the myelin fibers and the increase in the thickness of the internal retinal layer in optical coherence tomography found in our study have been noted in the literature [10].

\section{Conclusion}

Myelin fibers are asymptomatic, rare, benign affections that were discovered incidentally during an eye exam, the diagnosis is essentially clinical, based on an examination of the posterior segment of the eye. Para-clinical exams can help with diagnosis.

\section{Conflict of Interest}

No conflict of interest.

\section{Bibliography}

1. Hélène D., et al. "Anomalies congénitales de la papille". EMC (1996): 10.

2. Odoulami YL., et al. "A propos de deux cas évocateurs de fibres à myéline au Centre National Hospitalier et Universitaire Hubert Koutoukou Maga de Cotonou". Revue SOAO 1 (2012): 42-48.

3. Duval R., et al. "Acquired myelinated nerve fibers in association with optic disk drusen". Journal of American Association for Pediatric Ophthalmology and Strabismus 14.6 (2010): 544547.

4. Straatsma R., et al. "Myelinated retinal nerve fibers". American Journal of Ophthalmology 91 (1981): 25-38.

5. Kodama T., et al. "Myelinated retinal nerve fibers. Prevalence location and effect on visual acuity". Ophthalmologica 200 (1990): 77-83.

6. Laghmari M., et al. "Fibres à myéline péripapillaire étendues, myopie forte ipslatérale et amblyopie réfractaire". Journal Français D'Ophtalmologie 27.2 (2004): 188-190. 
7. French C., et al. "Evidence that migratory oligodendrocyte type 2 astrocyte (0-2a) progenitor celles are kept out of the rat retina by a barrier at the eye end of the optic nerve". Journal of Neurocytology 17.1 (1988): 13-25.

8. Tarabishy AB., et al. "Syndrome of myélinated retinal nerve fibers, myopia and amblyopia a review". Survey of Ophthalmology 52.6 (2007): 588-596.

9. Arda H., et al. "The results of electrophysiological tests in unilateral extensive peripapillary myelinated nerve fibers: report of three cases". Documenta Ophthalmologica 119.3 (2009): 225-228.

10. Combillet F., et al. "Fibres à myéline". Joint Field Office 35 (2012): 231-232.

\section{Assets from publication with us}

- Prompt Acknowledgement after receiving the article

- Thorough Double blinded peer review

- Rapid Publication

- Issue of Publication Certificate

- High visibility of your Published work

Website: www.actascientific.com/

Submit Article: www.actascientific.com/submission.php

Email us: editor@actascientific.com

Contact us: +919182824667 